
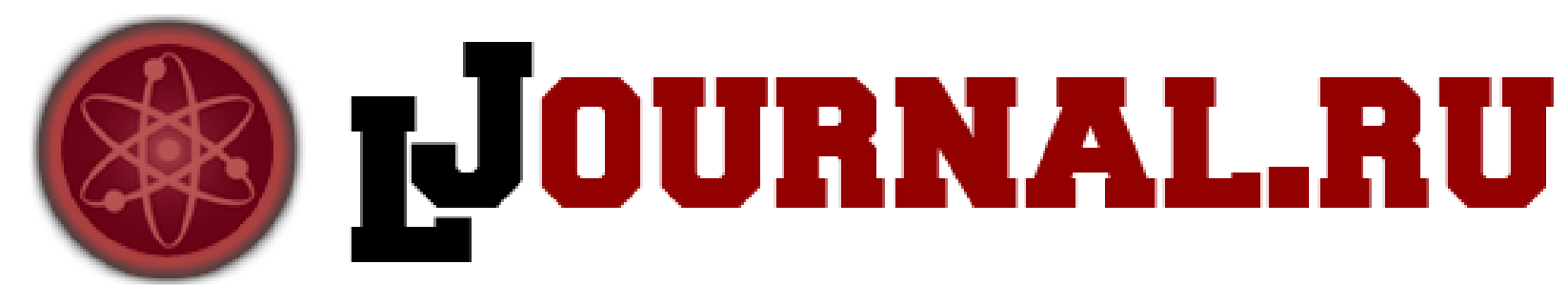

\author{
Левшина О.Н., Вакеев А.Б. \\ ФГБОУ ВПО «Санкт-Петербургский государственный \\ университет гражданской авиаџии» \\ Санкт-Петербург, Россия
}

doi: 10.18411/1j2016-2-11

\title{
Синергетическая парадигма в культурологии
}

C 70-х годов XX века начинается период становления постнеклассических наук, в контексте которых складывается синергетическая парадигма. Синергетика (греч. - совместно действующая) - междисциплинарное направление научных исследований, изучающее сложноорганизованные, открытые, нелинейные системы. У истоков синергетики стояли такие исследователи, как И.Р. Пригожин, Г. Хакен, М. Эйген, Дж. Лавлок, С.П. Курдюмов, С.П. Капица, Г.Г. Малинецкий, Е.Н. Князева, А.П. Назаретян и мн. др.

До появления синергетики, с точки зрения классической науки, все процессы, происходящие в мире, представлялись предсказуемыми на неограниченные промежутки времени, а эволюция рассматривалась как процесс, лишенный отклонений и возвратов. Роль случайности в мировом развитии исключалась как нечто внешнее и несущественное. Синергетика, напротив, придала фактору случайности решающее значение в процессе развития систем. $\mathrm{C}$ ее точки зрения, мир полон неожиданных поворотов, связанных с выбором дальнейшего пути развития. 
Синергетическая парадигма стирает грани между физическим и биологическим, природным и человеческим миром, и происходящими в них процессами. Она исходит из положения о том, что механизмы образования и разрушения структур, перехода от хаоса к порядку и наоборот едины для всех систем. Следовательно, синергетика - это не только наука, но и междисциплинарная парадигма, которая имеет широкие возможности применения не только в естественных, но и в гуманитарных науках.

Особенно плодотворным представляется сотрудничество синергетики и культурологии. Синергетическая парадигма открывает новые возможности познания закономерностей процесса развития культуры, и предвидения его результатов и перспектив. У истоков применения синергетической парадигмы в культурологии стояли такие известные исследователи как С.П. Курдюмов, Е.Н. Князева, М.С. Каган, Ю.М. Лотман, А.Я. Флиер, Л.М. Мосолова, В.В. Василькова и др.

В то же время, применяя синергетический подход в культурологии, необходимо учитывать тот факт, что в культуре происходит постоянное усложнение самоорганизации - движение от низшего уровня организации к высшему, поэтому культуру нельзя изучать также, как системы физического мира. В частности, М.С. Каган считал, что применительно к культуре общим законом синергетики следует считать не простейшую форму организации, а еe шкалу перехода в более сложные структуры. Своеобразие развития культуры он видел в том, что на появление нового в ней оказывает влияние не только случайность, но и такие качественные параметры, как саморазвитие, высокая степень саморефлексии, свобода и творчество [4. С. 28-50]. Поэтому при изучении культуры, как системы, необходимо учитывать качественные особенности антропо-социо-культурных систем. Это обстоятельство требует существенного пересмотра форм и методов познания, применяемых в синергетике, относительно анализа социокультурных явлений и процессов. 
В рамках синергетической парадигмы культура предстает как специфическое системное образование, развивающееся нелинейно, вариативно и случайно. Нелинейность означает, что в определенные периоды времени культура выходит из состояния устойчивого развития и дальнейшее ее развитие становится непредсказуемым. Момент, когда дальнейшее поведение системы становится непредсказуемым, называется точкой бифуркации (взрыва). В точке бифуркации происходит снятие внутрисистемных противоречий в культуре и выход на новый уровень организации. В этот момент перед культурой открывается множество вариантов дальнейшего развития системы и любой из них может стать определяющим [2. С. 21]. В качестве примера такого видения можно привести теорию М.С. Кагана о трех типах культуры, возникших в ходе неолитической революции. Так, по мнению исследователя, из первобытности вышли три параллельно развивавшихся типа хозяйства и соответственно три типа культуры: культура кочевников-скотоводов, культура земледельцев (культура Древнего Востока), культура ремесленников (античная культура).

Таким образом, в рамках синергетической парадигмы развитие культуры представляет собой чередование стабильного и переходного периодов, порядка и хаоса, закономерности и случайности. В.В. Василькова характеризует этот процесс следующим образом: «Периоды бурного бифуркационного рывка чередуются с периодами определенной структурной устойчивости воспроизводства десятилетиями, а иногда и столетиями сложившегося в определенное время порядка. Такие неповторимые сочетания и создают богатую палитру исторического многообразия человеческих цивилизаций» [1. С. 68].

Синергетическая парадигма позволяет по-новому взглянуть на процесс культурной динамики, в частности, определения природы движущих сил культурно-исторического процесса. Это обстоятельство создает условия для максимально широкого применения системно-синергетической парадигмы при изучении процесса развития культуры. 
В то же время необходимо отметить, что в культурно-исторических исследованиях, основанных на синергетической парадигме, большую сложность представляет проблема определения переходных и стабильных состояний культуры. Культура развивается неравномерно, а это значит, что взрывы в одних пластах культуры могут сочетаться с постепенным развитием в других. Это явление еще раз убеждает нас в том, что культура представляет собой сверхсложную систему, нуждающуюся в серьезном изучении с применением прогрессивных методик.

Синергетическая парадигма дает целостное понимание процесса развития культуры как чередования периодов порядка и хаоса, и позволяет выработать жизненную стратегию поведения и реагирования на процессы, происходящие в современном, полном противоречий мире. Зная механизмы самоорганизации, человек получает возможность корректировать и направлять развитие культуры в нужное ему русло, выводя ее на качественно новый уровень. От успешности управления данным процессом во многом будет зависеть выживание человека. В данном контексте трудно не согласиться со словами М.С. Кагана: «Синергетическое мышление, развивающее и конкретизирующее методологию системных исследований, открывает новые возможности познания закономерностей исторического процесса и предвидения перспектив его дальнейшего движения как единственной альтернативы полной дезорганизации общества, распада социальных связей и паралича культуры» [3. С. 219]. 


\section{Литература:}

1. Волновые процессы в общественном развитии / В.В. Василькова, И.П. Яковлев, И.Н. Барыгин и др. - Новосибирск: Изд-во Новосиб. ун-та, 1992. $227 \mathrm{c}$.

2. Ерохина Н.А., Прядеин В.С. Синергетика как методическая основа исторического познания (историографический анализ). - М.: Изд-во СГУ, 2006. $-208 \mathrm{c}$.

3. Каган М.С. Синергетика и культурология // Синергетика и методы науки: Сборник статей. - СПб.: Наука, 1998. - 438 с.

4. Каган М.С. Синергетическая парадигма - диалектика общего и особенного в методологии познания разных сфер бытия // Синергетическая парадигма: Нелинейное мышление в науке и искусстве: [Сборник]. - М.: ПрогрессТрадиция, 2002. - С. $28-50$. 